Vol. 9 (4): 751-756 (2019)

\title{
PRODUCTION OF BREAD FLOUR BY SOME CULTIVARS GROWN IN KOSOVO
}

\author{
Arsim Elshani $^{1}$, Nazmi Hasanaj ${ }^{2}$, Nexhdet Shala ${ }^{3}$, Kastriot Pehlivani ${ }^{4}$ \\ 1,2,3 University of "Haxhi Zeka", Faculty of Agribusiness, Peja 30000, Kosovo; \\ 2"Seed factory "Koal Seeds", Istog 30010, Kosovo; \\ ${ }^{4}$ University for business and technology, Food Science and Biotechnology, Pristina 10000, Kosovo; \\ *Corresponding Author Nazmi Hasanaj, e-mail: nazmihasanaj@unhz.eu;
}

Received September 2019; Accepted October 2019; Published November 2019;

DOI: https://doi.org/10.31407/ijees9421

\begin{abstract}
Based on the study on the quality assessment of harvested crops in the Kosovo region, certain flour and variety of baking products have been determined their chemical and technological properties and the possibility of adding additives (redox agents). The main types of grain cultivars cultivated in the republic of Kosovo are Luna, Isengrain, Europa, Lenta and Andolu, which are included in this study. To provide a clear picture of the abovementioned cultivars, the study includes detailed analysis of technological qualities starting with the preparation of cultivars for grinding, milling them where we have obtained two types of Tip-500 flour and tip-850, physicochemical and rheological analysis of flour, bread production, and analysis of bread production. The obtained physico-chemical and rheological analysis shows that cultivar flours, Luna and Lenta, have very similar and much better qualities than other cultivars. Also, the results of the produced bread show that the loaves produced by the Luna and Lenta cultivars have much better quality than the breads produced by the flour of other cultivars.
\end{abstract}

Keywords: Bread, Physical-Chemical Properties, Technological Properties, Wheat, $\alpha$-Amylase. 